مجلحت (لفنون والأدب وعلوه الإنسانيات والبانتهاع

Journal of Arts, Literature, Humanities and Social Sciences

ISSN online: 2414 - 3383

ISSN print: 2616 - 3810

أيلول - سبتهبر 2019

العدد (43)

\title{
The Powers of the President in Presidential and Parliamentary System (A comparative Study)
}

\author{
Dr. Hind Ali Mohammed \\ Colleg of Law - University of Misan \\ Iraq \\ fadc2012@yahoo.com
}

\begin{abstract}
Every community with pillars of a state, should have a highest head known as the President of the State. The President exercises his powers in the state, irrespective of its name. However, the presidential powers are not equally vested across the countries, but distinct to each state. In the system of the Republican presidential, the president is considered as the supreme leader with the ultimate exercutive power of the State and the government. On the contrary, President of the monarchy normally designates the prime minister to lead the government. Meanwhile, one of the presidential activities is the general overseeing of external and the internal state policies as well as the oversight of government activities. Also, the President of a State enjoys many authorities that overlap with executive and the legislative authorities and even within the judiciary tiers of govenemnt. On the other hand, the powers of the president in the parliamentary system, differes with those of the president in a presidential system. Thus, the powers of the president in a parliamentary system are are viewed as pro forma in the eyes of the ministry as he is responsible for his works, while Powers of the president in a presidential system are considered tangible in the eyes of his Congress.
\end{abstract}




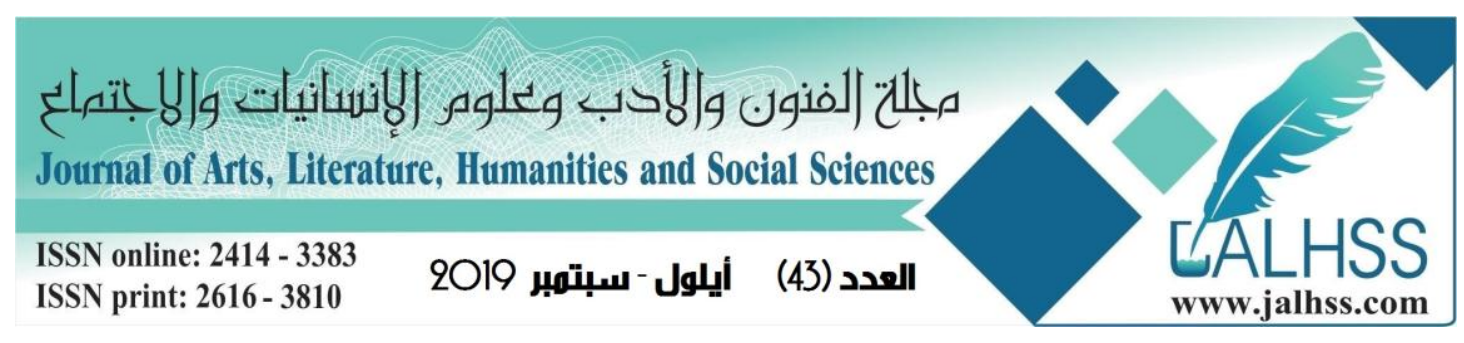

\section{Introduction}

The president of the state, is the king in a monarchy, and the President of a Republic in the Presidential system is an executive with executive powers in the Presidential system. The collective body such as the ministry emanates from Parliament, based on the confidence that expect to receive all of its members, or some of them, as is the case of a Captain in Britain. In contrast, the Head of State, ${ }^{1}$ in the US Constitution, the President of the United States of America, ${ }^{2}$ is the president of state and head of government at the same time. ${ }^{3}$ The executive power in the Presidential system is based on the principle of individual power. This means that a presedent of republic, hence, has executive jobs and power to control the State. ${ }^{4}$ The United States presidential system, was the first to exist and which determined the development and protection of its citizen's properties. The system later spread to many countries of the world, especially the Latin America. ${ }^{5}$ The presidential system is designed and operated based on the separation of powers in the state (i.e., legislative, executive and judicial).

\footnotetext{
${ }^{1}$ Captain: It is a collective body corporate exercise its powers under the authority of the Prime Minister, which is collectively responsible before the Council of of Commons, and this responsibility also includes members of the government from the outside (Captain) who did not participate in the decision-making, However, this responsibility is just a theory, because the Captain has the support of the majority in the House of Commons as a pop-up of it, the actual responsibility is the responsibility in front of the electorate, which held accountable Captain on his work, Captain work public policy formulation and implementation, and management of government departments, and the appointment of staff, see, Issam Suleiman, parliamentary systems between theory and practice,, Halabi legal publications, Beirut, Lebanon ,2010, p. 92.

${ }^{2}$ Edmund ligament, the mediator in the constitutional common law, Dar Ilm Lilmalayin, Beirut, Lebanon ,1965, p. 594.

${ }^{3}$ Abdul Hamid Metwally, in brief theories and political systems and constitutional principles, knowledge publishing house, Egypt 1959, p. 268.

${ }^{4}$ Ibrahim Abdul Aziz Al Shiha, the executive power mode (President of the State - the Ministry) in contemporary political systems, knowledge facility, Alexandria, 2006, p. 84.

${ }^{5}$ Mohammed Kazem al-Mashhadani, political systems, Cairo, 2008, p. 168.
} 


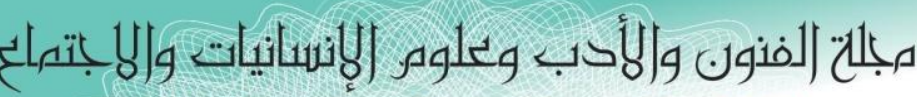

Journal of Arts, Literature, Humanities and Social Sciences

ISSN online: 2414 - 3383

ISSN print: 2616 - 3810

أيلول -سبتمبر 2019

العدد (43)

The separation of powers ensures the indepency of each tier of government from one another where each exercise its function without the interference of the other as specified in the Constitution.

The parliamentary system is based on close cooperation between the legislative and executive branch, in which the government is responsible before the parliament. Thus, the parliament's has right to withhold confidence from the government offset by the government's right to dissolve parliament. Parliamentary system of government has originated from England. Constitutional order in England as it is known is characterized by the duality of the executive branch, where a King has a role to play but is supervised by the state. However, the actual role of the ministry in the parliamentary system of government is attributed to the executive branch, which is also characterized by mutual cooperation of powers between the legislative and executive branches.

\section{Powers of the president of state in the Parliamentary System}

The parliamentary system is the political system made to achieve the separation of flexible authorities. This implies that it requires the permanent cooperation between the President of the State and parliament of the Ministerial Council, which by extension shares the view of governance with the President of the State. On the other hand, the president in parliementry systeme is accountable to the parliament. ${ }^{6}$ Also, the ministry is also answerable to the Parliament. Thus, in parliamentary system there is a sort of diffusion of power between the government and parliament as the parliament normally attempts to undermine the role of the ministry. In this case, the government may have recourse to the president of the state, requesting disposition to dissolve parliament and hold new elections in order to find out of wether the Parliament expresses the truth about the opinion of a majority of voters or not.

\footnotetext{
${ }^{6}$ Hamid Hannoun, political systems, faiek-Press, Baghdad, 2008, p 98.
} 


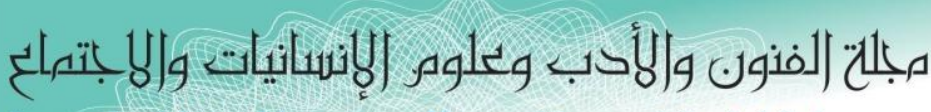

Journal of Arts, Literature, Humanities and Social Sciences

ISSN online: 2414 - 3383

ISSN print: 2616 - 3810

العدد (43) أيلول - سبتمبر 2019

The parliamentary system is based on the principle of separation of powers and a system based on the balance between the legislative and executive branches. ${ }^{7}$ Generally, all the authorities vested in this system are not conflicting with each other, hence, no one has control over the other. Therefore, in the attempt to ensure the maitaiance of balance between the legislative and executive branches, there is need to bring in a neutral person to restores the stability of this balance. Hence, this person is the president of the state who is given the task of formal functions. However, there is lack of responsibility for the results of its work, as there is no clear responsibility, except with the existence power, thus, where there is no power with absent responsibility. ${ }^{8}$ President of the State in a parliamentary system is not the prime minister as head of government is the Prime Minister or the so-called prime minister or the minister first. The President of a State is the President of Republic or King. ${ }^{9}$ Consequently, the most important characteristic of President of the State in a parliamentary system is the principle of the lack of responsibility, although, this principle varies depending on the form of government. For instance, if it is in a monarchy, there is no responsibility, but there is responsibility in the Republic. This is confined in a narrow range in the political situation. However, the President of the Republic is not politically responsible, but illegally responsible in the performance of his job. ${ }^{10}$ The role of President of the State is direct governance in a parliamentary system.

\footnotetext{
${ }^{7}$ Tharwat Badawi, political systems, the first part, Arab Renaissance Publishing House .1962, p23.

${ }^{8}$ Ali Yousef Shukri, The principles of constitutional law and political systems, Cairo, 2008, p. 146.

${ }^{9}$ Ismail el Ghazal, constitutions and political institutions, Ezzeddine Foundation for printing and publishing, Beirut, Lebanon,1996, p, 117.

${ }^{10}$ Hassan Hassan, constitutional law and the constitution in Lebanon, the second edition, Dar Al-Hayat Library, Beirut, Lebanon 0.1998, p103.
} 


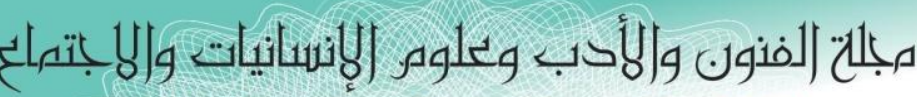

Journal of Arts, Literature, Humanities and Social Sciences

ISSN online: 2414 - 3383

ISSN print: 2616 - 3810

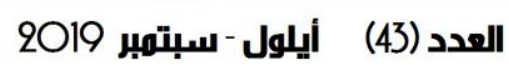

This is because it may be just a direct advice, then to guidance to the General State bodies, without having any direct role in governance, ${ }^{11}$ or the President of the state can direct the governance with the minstery in state, ${ }^{12}$ but in the same time the minstery should be to retain the confidence of Parliament. Also, the most of parliamentary constitutions decide for the President of the State, the legislative powers required such as the right to object a law. He also has the right to be issued with the terms of reference within the scope of the relationship between the legislative and the executive branch. He also has a right to invite parliament to convene parliaments or to resolve the parlamant. ${ }^{13}$

In the English parliamentary system, the King is normally found to have the absolute powers to oblige in (1215) signing of (Magna Carta). This in turn restricts the legislative powers in respect to financial laws as well as the King opens Parliament sessions and cast the throne speech, which shows the policy (His Majesty's Government). Afterwards, the parliament formed a committee to answer to the the throne speech, but indeed that, the actual work of power they say is not that, where, the parliament with full doing all the legislative process in stat, then he submit this work to the king, who has to be signed it. ${ }^{14}$ So the president of state in English parliamentary system, has no any powers, and could not make any personal policy. To that effect, the approapriate policy is made by the Council of Ministers who, normally does it to win the confidence of Parliament.

\footnotetext{
${ }^{11}$ Abdel Moneim Mahfouz and Noman Ahmed al-Khatib, the principles in political systems, Dar Al-Furqan for Publishing and Distribution, 1987, p. 280.

${ }^{12}$ Noman Ahmed al-Khatib, in the brief political systems, Saadi Press, 2004, p. 377.

${ }_{13}$ Mohsen Khalil, political systems and the Lebanese Constitution, the Arab Renaissance Publishing House, Beirut, 1979,p 123.

${ }^{14}$ Jawad Saleh and Ali Ghaleb al-Ani, political systems, Cairo, 2007, p 74-75.
} 


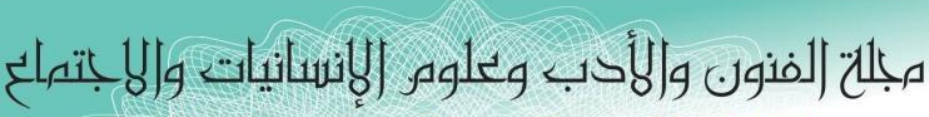

Journal of Arts, Literature, Humanities and Social Sciences

ISSN online: 2414 - 3383

ISSN print: 2616 - 3810

العدد (43) أيلول - سبتمبر 2019

Nevertheless, the king in Britain has historical value and regard to the British people as he is the symbol of unity of Britain and their people. ${ }^{15}$

In addition, the king is the only link that made the commonwealth witnessed its greatness through expansion of the British Empire. The commonwealth has about 33 members in the five continents of the world. Although, the Republic of Ireland withdrew in 1949 and the Union of South Africa in 1961. For the Commonwealth, the king is the only link between all the members of these States, and what connects the Great Britain with most of these States was the former colonies of Britain. ${ }^{16}$ Again, the King is an essential link between the citizens being led under the umbreller of the Anglican Church. ${ }^{17}$ In fact, the powers of the President of the State in a parliamentary system vary from one country to another. Thus, some of the powers of the President of the State in the parliamentary system is only or just an honorary authorities or a nominal but not real. These autorities include the appointment and dismissal of the staff, the appointment of ministers and their dismissal, the signing of treaties, the invitation to the parliament, postponement and resolutions. The use of the amnesty is in fact the powers of the a nominal President of the State, then, that the real role to the ministry responsible before the parliament. ${ }^{18}$ Based on this, the king of England can not single handedly act in any matters of state, or put public policy of the state in motion, nor put the draft laws as his personal opinion. Therefore, all of these issues are actually, left in the hands of the ministry in Charge of Parliament to handle.

\footnotetext{
${ }^{15}$ Mohammed Fathallah al-Khatib, studies in comparative governments, Arab Renaissance Publishing House, Beirut, 1966, p. 33

${ }^{16}$ Abdul Ghani Bassiouni, Authority and responsibility of the President of State in the parliamentary system, University Corporation for Studies and Publishing and Distribution, Beirut, 1995, p. 50

${ }^{17}$ Issam Suleiman, parliamentary systems between theory and practice, the first edition, publications Halabi human rights, Beirut, Lebanon, 2010,p45.

${ }_{18}$ Ibrahim Abdulaziz, Constitutional Law, University House for printing and publishing, Beirut, Lebanon, 1983, p31.
} 


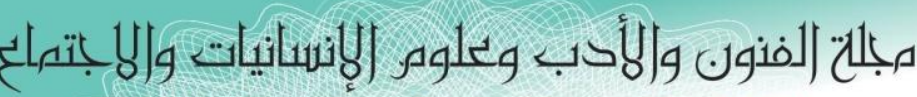

Journal of Arts, Literature, Humanities and Social Sciences

ISSN online: 2414 - 3383

ISSN print: 2616 - 3810

العدد (43) ايلول - سبتمبر 2019

\section{Powers of the President of the State in the presidential system}

The Presidential system, has arisen in the United States, the basic characteristics of this system is found written in the US Constitution which was created in the Villadwia Conference in 1787. The studies shows that the customary traditions and constitutional developments have contributed with a written constitution in determining the characteristics of this system even, in developing sometimes accordance with the requirements of work. A Presidential system derived its name from the President of the Republic, where the authors wanted to strengthen the US Constitution Center, President of the Republic and the strengthening of the actual authority. ${ }^{19}$ Thus, the Presidential system is distinguished from other systems on limition of the executive authority to the head of state. ${ }^{20}$ This is evident as the presidential system has separation of powers between three arms of government: executive, legislative and judicial. Accordingly, this system is characterized by work on the distribution of power on different bodies, of all that an independent body be fully independent from the other without the slightest control or cooperation between them. The legislature is independent from the other two arms in the exercise of its powers, without the presence of, association of, cooperation of, or direct mutual relationship between their terms of reference. Thus, the most important foundations of this system which this paper viewed is that the presidential system is the individually executive. ${ }^{21}$ The optimal model for the presidential system is the constitutional system of the United States of America.

\footnotetext{
${ }^{19}$ Mohamed Refaat Abdel Wahab, Hussein Osman Mohamed Osman, political systems, Dar university publications, Alexandria,2001, p 342.

${ }^{20}$ Wahid Raafat and White Ibrahim, constitutional law, modern printing press, Egypt, 1937, p. 333.

${ }^{21}$ Mohsen Khalil, ibid, P,404.
} 


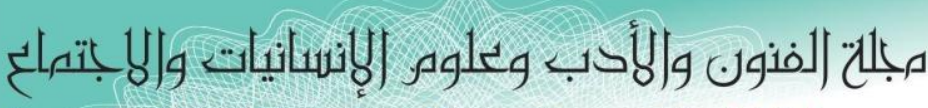

Journal of Arts, Literature, Humanities and Social Sciences

ISSN online: 2414 - 3383

ISSN print: 2616-3810

العدد (43) ايلول -سبتمبر 2019

A presidential system have a wider terms of reference compared with the terms of reference enjoy by the President of the State in parliamentary countries. ${ }^{22}$

The reason for this widening is that the US president's power is centered on the president's hands alone. Again, the power to manage the state affairs is the sole responsibility of the president. Thus, the most important terms of reference of the US President are to ensure the implementation of laws, issue necessary orders, the leadership of the armed forces, also, his powers to draw foreign policy, and supervise its implementation, as well as overseeing the functioning of the government apparatus, his administration, appoint ministers, dismiss ministers and determine their competence. The president works and provides the congress with information from time to time. The president is given recommendations to take the necessary measures via sending messages to him and the issuance of special amnesty. ${ }^{23}$ In light of the above, it is obvious that the powers of President of the State in the presidential system are numerious and wide in both military and civilian fields, thus, the President of the State in the presidential system, has an outstanding and effective exercise in all manifestations of power in the state without a minister. Except that the other excercutives works as the president assistants on the implementation of the policy, as drawn by him and determined by them.

\section{Conclusion and Recommendations for future Studies}

\section{Conclusion}

Authorities of the President of the State differs from one country to another, according to the nature of the political and constitutional system. Sometimes, these authorities are absolute and effective.

\footnotetext{
${ }^{22}$ Mohamed Kamel Leila, political systems, the renaissance of Egypt Press, Cairo 1961,p 232.

${ }^{23}$ Shomran Hammadi, the principles of political systems, civil Publishing and Printing, Baghdad, 1967, p. 181.
} 


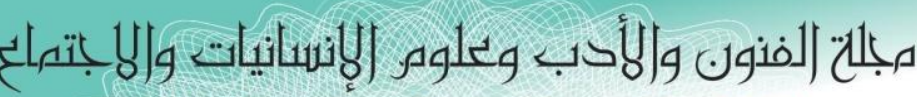

Journal of Arts, Literature, Humanities and Social Sciences

ISSN online: 2414 - 3383

ISSN print: 2616-3810

العدد (43) ايلول -سبتمبر 2019

This paper reflects the reality of dealing within the executive branch, other times, its powers, proformance and symbolic powers in most of them seems as is the case in the traditional parliamentary system. On the other hand, the paper pointed out that the President of the State authorities, are in fact actual and seem to have a strong power, in the presidential system. Thus, the President of the Republic has very wide powers, in the field of relationship with the government. therefore, the government as a whole can not oppose the President in decision-making in the state.

\section{Recommendations for Future Studies}

Based on this research, it is found that, the constitution is indeed different from the political reality of certain countries concerning the powers of the President of the State. This implies that, the constitutional provisions do not give the head of state, just only limited powers are almost pro forma, while, the political reality refers to the actual enjoyment of President's powers outside the constitutional provisions, there is no doubt that such indeed in the constitutional text and ambiguity generates opposes such cases, which is a clear violation of the provisions of the constitution. Here, we must develop solutions and treatments of a constitutional judiciary specialist in order to stop such failures and excesses of the constitutional text and be very means in respect of the constitution and to prevent violation. In fact, the existence of a constitutional motion spend the first of the conditions achieved full independence of the judiciary and the impartiality so that, it is away from political conflicts and consists of members with competence in the field of constitutional and legal work that is aimed at achieving the legal state which respects the rights and freedoms of individuals and protect the constitution. 


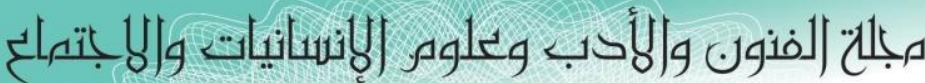

Journal of Arts, Literature, Humanities and Social Sciences

ISSN online: 2414 - 3383

ISSN print: 2616 - 3810

العدد (43) ايلول - سبتمبر 2019

\section{References}

1. Abdul Ghani Bassiouni, Authority and responsibility of the President of State in the parliamentary system, University Corporation for Studies and Publishing and Distribution, Beirut, 1995,

2. Abdul Hamid Metwally, in brief theories and political systems and constitutional principles, knowledge, publishing house, Egypt 1959,

3. Ali Yousef Shukri, The principles of constitutional law and political systems, Cairo, 2008,

4. Edmund ligament, the mediator in the constitutional common law, Dar Ilm Lilmalayin, Beirut, Lebanon, 1965.

5. Hassan Hassan, constitutional law and the constitution in Lebanon, the second edition, Dar Al-Hayat Library, Beirut, Lebanon, 1998.

6. Ibrahim Abdul Aziz Al Shiha, the executive power mode (President of the State the Ministry) in contemporary political systems, knowledge facility, Alexandria, 2006, p. 84.

7. Ibrahim Abdulaziz, Constitutional Law, University House for printing and publishing, Beirut, Lebanon, 1983.

8. Ismail Al- Ghazal, constitutions and political institutions, Ezzeddine Foundation for printing and publishing, Beirut, Lebanon, 1996.

9. Issam Suleiman, parliamentary systems between theory and practice, Halabi legal publications, Beirut, Lebanon, 2010.

10. Issam Suleiman, parliamentary systems between theory and practice, the first edition, publications Halabi human rights, Beirut, Lebanon, 2010,

11. Mohamed Kamel Leila, political systems, the Renaissance of Egypt Press, Cairo 1961,

12. Mohamed Refaat Abdel Wahab, and Hussein Osman Mohamed Osman, political systems, Dar university publications, Alexandria, 2001, 


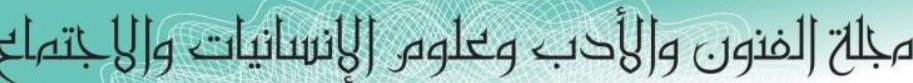

Journal of Arts, Literature, Humanities and Social Sciences

ISSN online: 2414 - 3383

ISSN print: 2616 - 3810

أيلول -سبتمبر 2019

العدد (43)

13. Mohammed Fathallah al-Khatib, studies in comparative governments, Arab Renaissance Publishing House, Beirut, 1966.

14. Mohammed Kazem al-Mashhadani, political systems, Cairo, 2008,

15. Shomran Hammadi, the principles of political systems, civil Publishing and Printing, Baghdad, 1967.

16. Tharwat Badawi, political systems, the first part, Arab Renaissance Publishing House .1962,

17. Wahid Raafat and White Ibrahim, constitutional law, modern printing press, Egypt, 1937. 